\title{
Efficiency of Two Different Synchronization Protocols in Conception in Simmental Heifers
}

\author{
Gaye BULUT'1 ${ }^{1}$ Umut TAŞDEMİR ${ }^{2 *}$ \\ 1 Aksaray University, Faculty of Veterinary Medicine, Department of Obstetric and Gyneacology, 68100, Aksaray, Turkey \\ ${ }^{2}$ Aksaray University, Technical Sciences Vocational School, 68100, Aksaray, Turkey
}

\begin{abstract}
This study aimed to reveal the effects of timed artificial insemination applied after the synchronization protocol known as day5 (D5) and the prostaglandin F2 $\alpha$ (PGF2 $\alpha$ ) protocol applied in 11-day intervals (D11) on pregnancy rates in Simmental heifers. A total of 88 heifers were divided into two treatment groups. In the D5 group (n: 56), after gonadotrophin releasing hormone (GnRH) application, PGF2 $\alpha$ injection was made on the 5th day and the second PGF2 $\alpha$ injection was given one day later. The second GnRH was applied at the time of TAI and at the 44th hour of the second PGF2 $\alpha$ application. In the D11 group (n: 32), double-dose PGF2 $\alpha$ was given in 11-day intervals. GnRH was applied at the time of TAI and at the 81 st hour following the second PGF2 $\alpha$ injection. Pregnancy-associated glycoprotein visual test was carried out for determining to pregnancy on the 28th day. Additionally, for the purpose of determining embryonic deaths, the pregnancies were checked again by ultrasonography on the 63rd day following TAI. The 28th-day pregnancy rates in the synchronized heifers were $51.8 \%(29 / 56)$ in the D5 group and $43.8 \%(14 / 32)$ in the D11 group $\mathrm{P}>0.05$. The 63rd-day pregnancy rates were $48.21 \%(27 / 56)$ in the D5 group and $40.62 \%(13 / 32)$ in the D11 group $\mathrm{P}>0.05$. Consequently, although there was no statistically significant difference in terms of pregnancy rates between the D5 and D11 protocols, there was a numerical increase in the D5 protocol. Considering its short application time, D5 may be used for TAI in Simmental heifers.
\end{abstract}

Keywords: GnRH, Heifer, PGF2 $\alpha$, Synchronization, Timed Artificial Insemination

\section{$* * *$ \\ Simental Düvelerde Farklı İki Senkronizasyon Protokolünün Gebelik Üzerine Olan Etkinliği \\ ÖZ}

Bu çalışma ile day5 (D5) olarak isimlendirilen senkronizasyon protokolü ile 11 gün aralıklarla uygulanan PGF2 $\alpha$ (D11) protokolü sonrasında yapılan zaman ayarlı suni tohumlamanın (TAI) kombine verimli bir ırk olan Simmental düvelerde gebe kalma oranı üzerine etkilerinin ortaya konması amaçlandı. 88 adet düve rastgele iki tedavi grubuna ayrıldı. D5 grubuna (n: 56), GnRH uygulamasının ardından 5. günde PGF2 $\alpha$ enjeksiyonu yapıldı ve bir gün sonra ikinci PGF2 $\alpha$ verildi. İkinci GnRH, TAI zamanında, ikinci PGF2 $\alpha$ uygulamasından 44 saat uyguland1. D11 grubuna (n: 32) ise, çift doz prostaglandin PGF2 $\alpha 11$ gün araliklarla verildi, GnRH TAI zamanında, ikinci PGF2 $\alpha$ enjeksiyonunu takiben 81. saatte uygulandi. Gebelikleri belirlemek amaciyla 28. günde gebelik ile ilişkili proteinlerin belirlenmesine yönelik pregnant association glycoprotein (PAG) testi uygulandı. Ayrıca, TAI'yi takiben 63. günde embriyonik ölümlerin belirlenmesi amacıyla ultrasonografi ile gebelikler tekrar kontrol edildi. Sekronize adilen düvelerde 28. gün gebelik oranlar1 D5 grubunda \%51.8 (29/56) ve D11 grubunda $\% 43.8$ (14/32) oranındaydı $\mathrm{P}>0.05$. 63. gün gebe kalma oranları $\mathrm{D} 5$ grubunda $\% 48.21(27 / 56)$ ve D11 grubunda \%40.62 (13/32) olarak tespit edildi P >0.05. Sonuç olarak, D5 protokolü D11 protokolü ile karşılaştırıldığında gebelik üzerine etkisi istatistiksel olarak farklı bulunmamasına rağmen, rakamsal olarak yüksek bulundu. Uygulama süresinin kısa olması da göz önüne alındığında Simmental düvelerde TAI amacıyla kullanılabilir.

Anahtar Kelimeler: GnRH, Düve, PGF2 $\alpha$, Senkronizasyon, Zaman Ayarlı Suni Tohumlama

To cite this article: Bulut G. Taşdemir U. Efficiency of Two Different Synchronization Protocols in Conception in Simmental Heifers. Kocatepe Vet J. (2020) 13(2):140-144 


\section{INTRODUCTION}

Fertility is one of the most important components of efficient and profitable dairy cattle breeding (Kuhn et al. 2006). However, there is a negative correlation between milk yield and fertility, heifers are selected based on their milk yield in establishments that breed dairy cattle. While heritability has a low effect on fertility, considering the fertility outcomes obtained today, this approach has led to a decrease in fertility in comparison to the past, and with this decrease, studies on fertility have increased in numbers (VanRaden et al. 2004). Artificial insemination (AI) is a technique that is prevalently used worldwide for animal breeding and obtaining generations with superior genetic characteristics (Bó and Baruselli 2014). Moreover, AI comes to the fore as additional feeding costs are eliminated by not including bulls that need to be included in cases of natural insemination, it is more inexpensive, it prevents diseases that are transmitted by mating and it provides results that are similar to those obtained by natural mating (Ribeiro et al. 2012).

Estrus synchronization, on the other hand, is not only a practical tool for reproduction management of dairy (Pursley et al. 1997) and beef (Patterson et al. 2003) cattle, but it also provides advantages in terms of reducing the usage of inputs of time and labor, and thus, several studies have focused on development of estrus synchronization techniques for productive synchronization of estrus (Schmitt et al. 1996). Estrus synchronization protocols are a set of methods that are applied to control follicular growth and ovulation by applying hormones (Bó et al. 2016). As these protocols reduce the first $\mathrm{AI}$ interval and increase AI usage in stock dairy heifers, they allow timed artificial insemination (TAI) procedures without needing estrus determination (Peeler et al. 2004, Ribeiro et al. 2012). However, as the pregnancy success rates obtained from heifers with TAI that is applied after synchronization protocols are lower than that in cows, usage of synchronization protocols in heifers has remained limited (Pursley et al. 1997). On the other hand, recent studies have reported that 50-60\% successful pregnancies could be obtained from a 5day synchronization program applied on heifers (Rabaglino et al. 2010, Silva et al. 2015) and the pregnancy rates obtained with this protocol were similar to the outcomes obtained by AI applied after estrus monitoring (Kuhn et al. 2006, Silva et al. 2015). Lima et al. (2013) asserted that ovulation time could be adjusted in heifers with a 5-day synchronization protocol, and this way, it is an attractive alternative for breeders in terms of achievement of pregnancy in a shorter time in heifers. However, synchronization studies have usually been carried out on Holstein heifers so far, and there are a few to no studies on combined breeds. For this reason, this study aimed to reveal the effects of TAI applied after the synchronization protocol known as day5 (D5) and the prostaglandin F2 $\alpha$ (PGF2 $\alpha$ ) protocol applied in 11day intervals (D11) on pregnancy rates in Simmental heifers, which are a combined breed.

\section{MATERIALS and METHODS}

\section{Heifers}

The study was conducted between March and September 2018 and included Simmental heifers at the ages of 14 to 20 months (mean: 17.1 months). The heifers were obtained from a herd that was being bred at THS Livestock (Gölbaşı, Ankara, Turkey), did not have any genital or contagious diseases and had a purebred herd certificate. Before starting the study, to determine whether or not the heifers were cyclic, an ultrasound device was used with a $5-\mathrm{MHz}$ probe (ImaGo S, IMV, France). The heifers that had at least one functional corpus luteum were accepted as cyclic. The heifers were put in a semi-open cowshed. They were fed with a balanced mixed ration that corresponded to their daily feed requirements based on the directives of the National Research Council (2001) and water intake was provided as ad libitum. The sperm that was used in AI was supplied from a company (Masttering Genetic, Hohenzell, Austria) that produced sperm. Animal experiments were carried out in accordance with the directive 2010/63/EU of the European Parliament and of the Council of Europe on the protection of animals used for scientific purposes.

\section{Synchronization protocols and determination of pregnancy rates}

A total of 88 heifers were used in the study, and the heifers were divided into two treatment groups. In the D5 group (n: 56), after gonadotrophin releasing hormone $(\mathrm{GnRH} ; 100 \mu \mathrm{g}$, im, gonadorelin diasetat, Ovarelin, Ceva, Turkey) application, PGF2 $\alpha$ (25 mg, im, dinoprost, Dinolytic, Zoetis, Turkey) injection was made on the 5th day and the second PGF2 $\alpha$ injection was given one day later. The second GnRH was applied at the time of TAI and at the 44th hour of the second PGF $2 \alpha$ application (GnRH-5dPGF $2 \alpha-1 d-P G F 2 \alpha-44 h$ TAI and GnRH). In the D11 group (n: 32 ), double-dose PGF2 $\alpha$ was given in 11-day intervals. GnRH was applied at the time of TAI and at the 81st hour following the second PGF2 $\alpha$ injection (PGF2 $\alpha-11 \mathrm{~d}-$ PGF $2 \alpha-81 \mathrm{~h}$ TAI and GnRH). TAI was carried out by an same experienced expert. To determine pregnancies, on the 28th day, pregnancy-associated glycoprotein (PAG) test was carried out for determining to pregnancy as described by Bulut et al. (2018). Bluish color changes as a result of the PAG test were accepted as positive pregnancy. Additionally, for the purpose of determining embryonic deaths, the pregnancies were checked again by ultrasonography on the 63rd day following TAI. The presence of a fetus on the 63rd day 
following TAI was determined as an indicator of pregnancy.

\section{Statistical Analysis}

Analysis of the data were performed by using a computer software SPSS for windows (version 22.0). The effect of protocols (D5; D11) on pregnancy rates were computed using chi-square analysis. The level of significance was held at $\mathrm{P}<0.05$ to show statistically significant differences among variables.

\section{RESULTS}

The pregnancy rates of the heifers determined on the 28th day (d28) were similar between the groups, the 28th-day pregnancy rates in the synchronized heifers were $51.8 \%(29 / 56)$ in the D5 group and $43.8 \%$ $(14 / 32)$ in the D11 group $\mathrm{P}>0.05$. When the two groups were analyzed based on their 63rd-day pregnancy rates, there was no statistically significant difference. The 63rd-day pregnancy rates were $48.21 \%(27 / 56)$ in the D5 group and $40.62 \%(13 / 32)$ in the D11 group $\mathrm{P}>0.05$.

\section{DISCUSSION}

The first synchronization protocol to synchronize ovulation was used by Pursley et al. (1995) in 1995. The effects of TAI after ovulation synchronization on pregnancy were evaluated for the first time with this protocol. With this protocol named Ovsynch, while successful results were obtained in cows, the outcomes obtained in heifers were not considered much satisfactory. Studies have shown that only 43$60 \%$ of dairy and beef heifers ovulate as a response to GnRH (Pursley et al. 1997), while 64-75\% of dairy and beef cows ovulate in response to a similar treatment (El-Zarkouny et al. 2004). It is argued that this difference is caused by the ovary follicular dynamic. Considering the results of previous studies, it was reported that there is a positive relationship between follicular development and pregnancy rates, follicular diameters of higher than 10.8 will turn into a corpus luteum with a desired size in the next diestrus period, and this corpus luteum that is formed will have positive effects on pregnancy rates by causing sufficient amounts of progesterone secretion (Martins et al. 2014). For this reason, within time, different synchronization protocols have been studied in cows (Tenhagen et al. 2004, Wiltbank et al. 2011) and heifers (Stevenson et al. 2008) with the purpose of synchronizing ovulation. Recent studies reported higher rates of success in studies with GnRH and PGF $2 \alpha$ in comparison to those with only PGF2 $\alpha$ (Archbald et al. 1992, Dahlen et al. 2003). Application of PGF $2 \alpha$ with $\mathrm{GnRH}$ to synchronize the estrous cycle has been demonstrated to induce ovulation, shorten the cycle and increase the embryo quality
(Vasconcelos et al. 1999). Additionally, as the strongest response to $\mathrm{GnRH}$ is between the 5th and 8th days of the estrous cycle (Atkins et al. 2008), it was reported that pre-synchronization practices applied on heifers before the first GnRH application have a positive contribution on pregnancy outcomes (Leitman et al. 2008). In this study, although there was no statistically significant difference between the D5 and D11 protocols in terms of pregnancy rates, it was determined as a significant advantage of the D5 protocol that its application time is shorter. In the D5 protocol, it is though that ovulation in the ovaries in the follicular period is triggered by the first $\mathrm{GnRH}$ application, regression of the corpus luteum is achieved in the ovaries by applying PGF2 $\alpha$ in 24 intervals on heifers all of which are in their diestrus period at the end of the 5th day, and the newly developed follicle afterwards has a more positive effect on the pregnancy rates. In comparison to similar studies, the rates of pregnancy in this study were found to be higher. Such that, the pregnancy rate was obtained as $12 \%$ in a study which applied PGF2 $\alpha$ with a 12-day interval in beef heifers and facilitated TAI 6 hours after the last PGF2 $\alpha$ injection. In the same study, GnRH was applied on the 6th day following the first PGF2 $\alpha$ application, PGF $2 \alpha$ was given on the 12th day after the first PGF2 $\alpha$ application, and GnRH+TAI was implemented 2 days later, but the pregnancy outcomes were still low (22.1\%) (Dahlen et al. 2003). Tenhagen et al. (2005) applied PGF2 $\alpha$ on Holstein-Friesian heifers 7 days after $\mathrm{GnRH}$ application, they facilitated TAI on the 48th and 72nd hours following the last PGF2 $\alpha$ application, and they obtained similar pregnancy rates to those in this study $(52.8 \%$ on the 48 th hour, $49.0 \%$ on the 72th hour). In difference to this study, in a study where the CIDIR-PGF2 $\alpha$ protocol was used for 14 days, it was proposed that simultaneous usage of GnRH with TAI did not have a positive effect on pregnancy rates in cases of estrus monitoring (Bishop et al. 2017).

On the other hand, this study produced a lower rate of pregnancy in comparison to those in many others. In a study on Angus heifers, 55.0\% pregnancy rate after the controlled internal drug release (CIDR) protocol and $66.0 \%$ pregnancy rate after CIDR select and PGF2 $\alpha$ application were obtained (Leitman et al. 2009). In a study on heifers that were synchronized by intravaginal progesterone administration, estradiol cypionate (ECP) and PGF2 $\alpha$ which were monitored for estrus later, the pregnancy rate was determined as $60.1 \%$ (Peeler et al. 2004). A previous study of our group divided Holstein-Friesian heifers that were synchronized by two PGF2 $\alpha$ applications with a 14day interval into two groups, and in the first group, GnRH was applied at the 56th hour following the second PGF2 $\alpha$, and TAI was performed at the 16th- 
18th hours following GnRH injection. In the second group, GnRH was applied 62 hours after the second PGF2 $\alpha$ simultaneously with TAI. We achieved the pregnancy rates of $59.8 \%$ in the first group and $55.3 \%$ in the second group (Taşdemir et al. 2011). In their synchronization program, Ahmadzadeh et al. (2015) reported that they applied 5 and 7 days of CIDIR, they carried out artificial insemination by PGF2 $\alpha$ application, the 5-day protocol provided better results on pregnancy (64.5\%), and application of $\mathrm{GnRH}$ at the beginning of the synchronization program did not have an advantage. Considering the results that were obtained, it is believed that the differences in the studies were caused by that the heifers were in the different periods of their estrous cycle during hormone applications, and different responses developed against the hormones that were applied.

Consequently, although there was no statistically significant difference in terms of pregnancy rates between the D5 and D11 protocols, there was a numerical increase in the D5 protocol. Considering its short application time, D5 may be used for TAI in Simmental heifers.

\section{ACKNOWLEDGEMENTS}

"This study was presented III. International Congress on Advances in Veterinary Sciences and Technics, BelgradeSerbia, September 05-09, 2018”.

"The authors thank. THS Livestock (Gölbaşı, Ankara, TURKEY) for the use of their facilities and herd".

Conflict of Interest: The authors declare that they have no conflict of interest.

\section{REFERENCES}

Ahmadzadeh A, Gunn D, Hall JB, Glaze JB. Evaluation of treatment with a 5-day versus 7-day controlled internal drug-release insert on reproductive outcomes of beef heifers using a modified timed-artificial insemination protocol. Prof. Anim. Sci. 2015; 31(3): 270-277.

Archbald LF, Tran T, Massey R, Klapstein E. Conception rates in dairy cows after timed-insemination and simultaneous treatment with gonadotrophin releasing hormone and/or prostaglandin F2 alpha. Theriogenology. 1992; 37(3): 723-731.

Atkins JA, Busch DC, Bader JF, Keisler DH, Patterson DJ, Lucy MC, Smith MF. Gonadotropin-releasing hormone-induced ovulation and luteinizing hormone release in beef heifers: Effect of day of the cycle. J. Anim. Sci. 2008; 86(1): 83-93.

Bishop BE, Thomas JM, Abel JM, Poock SE, Ellersieck MR, Smith MF, Patterson DJ. Split-time artificial insemination in beef cattle: III. Comparing fixed-time artificial insemination to split-time artificial insemination with delayed administration of $\mathrm{GnRH}$ in postpartum cows. Theriogenology. 2017; 99: 48-52.
Bó GA, Baruselli PS. Synchronization of ovulation and fixedtime artificial insemination in beef cattle. Animal. 2014; 8(1): 144-150.

Bó GA, de la Mata JJ, Baruselli PS, Menchaca A. Alternative programs for synchronizing and resynchronizing ovulation in beef cattle. Theriogenology. 2016; 86(1): 388-396.

Bulut G, Taşdemir U, Yıldırım AÇ. The efficiency pregnancy associated glycoproteins in pregnancy diagnosis. III International Congress on Advances in Veterinary Sciences and Technics. 2018. pp. 89.

Dahlen CR, Lamb GC, Zehnder CM, Miller LR, DiCostanzo A. Fixed-time insemination in peripuberal, lightweight replacement beef heifers after estrus synchronization with PGF2alpha and GnRH. Theriogenology. 2003; 59(8): 1827-1837.

El-Zarkouny SZ, Cartmill JA, Hensley BA, Stevenson JS. Pregnancy in dairy cows after synchronized ovulation regimens with or without presynchronization and progesterone. J. Dairy Sci. 2004; 87: 1024-1037.

Kuhn MT, Hutchison JL, Wiggans GR. Characterization of Holstein heifer fertility in the United States. J. Dairy Sci. 2006; 89(12): 4907-4920.

Leitman NR, Busch DC, Bader JF, Mallory DA, Wilson DJ, Lucy MC, Patterson DJ. Comparison of protocols to synchronize estrus and ovulation in estrous-cycling and prepubertal beef heifers. J. Anim. Sci. 2008; 86(8): 18081818.

Leitman NR, Busch DC, Mallory DA, Wilson DJ, Ellersieck MR, Smith MF, Patterson DJ. Comparison of longterm CIDR-based protocols to synchronize estrus in beef heifers. Anim. Reprod. Sci. 2009; 114(4): 345-355.

Lima FS, Ribeiro ES, Bisinotto RS, Greco LF, Martinez N, Amstalden M, Santos JEP. Hormonal manipulations in the 5-day timed artificial insemination protocol to optimize estrous cycle synchrony and fertility in dairy heifers. J. Dairy Sci. 2013; 96(11): 7054-7065.

Martins T, Peres RFG, Rodrigues ADP, Pohler KG, Pereira MHC, Day ML, Vasconcelos JLM. Effect of progesterone concentrations, follicle diameter, timing of artificial insemination, and ovulatory stimulus on pregnancy rate to synchronized artificial insemination in postpubertal Nellore heifers. Theriogenology. 2014; 81(3): 446-453.

National Research Council. Nutrient Requirements of Dairy Cattle, Seventh Revised Edition, Washington DC, The National Academies Press, 2001. https://doi.org/10.17226/9825

Patterson DJ, Kojima FN, Smith MF. Methods to Synchronize Estrous Cycles of Postpartum Beef Cows with Melengestrol Acetate. Prof. Anim. Sci. 2003; 19(2): 109_ 115.

Peeler ID, Nebel RL, Pearson RE, Swecker WS, Garcia A. Pregnancy rates after timed AI of heifers following removal of intravaginal progesterone inserts. J. Dairy Sci. 2004; 87(9): 2868-2873.

Pursley JR, Mee MO, Wiltbank MC. Synchronization of ovulation in dairy cows using PGF2 $\alpha$ and GnRH. Theriogenology. 1995; 44: 915-923.

Pursley JR, Wiltbank MC, Stevenson JS, Ottobre JS, Garverick HA, Anderson LL. Pregnancy Rates Per Artificial Insemination for Cows and Heifers Inseminated at a Synchronized Ovulation or Synchronized Estrus. J. 
Dairy Sci. 1997; 80(2): 295-300.

Rabaglino MB, Risco CA, Thatcher MJ, Kim IH, Santos JEP, Thatcher WW. Application of one injection of prostaglandin $\mathrm{F} 2 \alpha$ in the five-day $\mathrm{Co}-\mathrm{Synch}+\mathrm{CIDR}$ protocol for estrous synchronization and resynchronization of dairy heifers. J. Dairy Sci. 2010; 93(3): 1050-1058.

Ribeiro ES, Galvão KN, Thatcher WW, Santos JEP. Economic aspects of applying reproductive technologies to dairy herds. Anim. Reprod. 2012; 9(3): 370-387.

Schmitt EJ, Diaz T, Drost M, Thatcher WW. Use of a gonadotropin-releasing hormone agonist or human chorionic gonadotropin for timed insemination in cattle. J. Anim. Sci. 1996; 74(5): 1084

Silva TV, Lima FS, Thatcher WW, Santos JEP. Synchronized ovulation for first insemination improves reproductive performance and reduces cost per pregnancy in dairy heifers. J. Dairy Sci. 2015; 98(11): 7810-7822.

Stevenson JL, Dalton JC, Santos JEP, Sartori R, Ahmadzadeh A, Chebel RC. Effect of synchronization protocols on follicular development and estradiol and progesterone concentrations of dairy heifers. J. Dairy Sci. 2008; 91(8): 3045-3056.

Taşdemir U, Yilmazbaş-Mecitoğlu G, Keskin A, Karakaya E, Çelik Y, Güzeloğlu A, Gümen A. Conception rate following timed artificial insemination protocols in dairy heifers synchronised by PGF $2 \alpha$ and GnRH. Ank. Üniv. Vet. Fak. Derg. 2011; 58: 135-139.

Tenhagen BA, Drillich M, Surholt R, Heuwieser W. Comparison of timed AI after synchronized ovulation to AI at estrus: Reproductive and economic considerations. J. Dairy Sci. 2004; 87(1); 85-94.

Tenhagen BA, Kuchenbuch S, Heuwieser W. Timing of ovulation and fertility of heifers after synchronization of oestrus with GnRH and prostaglandin F2 $\alpha$. Reprod. Dom. Anim. 2005; 40(1): 62-67.

VanRaden PM, Sanders AH, Tooker ME, Miller RH, Norman HO, Kuhn MT, Wiggans GR. Development of a national genetic evaluation for cow fertility. J. Dairy Sci. 2004; 87(7): 2285-2292.

Vasconcelos JLM, Silcox RW, Rosa GJM, Pursley JR, Wiltbank MC. Synchronization rate, size of the ovulatory follicle, and pregnancy rate after synchronization of ovulation beginning on different days of the estrous cycle in lactating dairy cows. Theriogenology. 1999; 52(6): 1067-1078.

Wiltbank MC, Sartori R, Herlihy MM, Vasconcelos JLM, Nascimento AB, Souza AH, Gumen A. Managing the dominant follicle in lactating dairy cows. Theriogenology. 2011; 76; 1568-1582. 